BRAZIULIAN JOURNAL

OF MEDICAL AND BIOLOGICAL RESFARCH

www.bjournal.com.br
ISSN 0100-879X

Volume 44 (11) 1070-1193 November 2011

BIOMEDICAL SCIENCES

AND

CLINICAL INVESTIGATION

Braz J Med Biol Res, November 2011, Volume 44(11) 1118-1124

doi: 10.1590/S0100-879X2011007500128

Testosterone therapy delays cardiomyocyte aging via an androgen receptor-independent pathway

L. Zhang, S.Z. Wu, Y.J. Ruan, L. Hong, X.W. Xing and W.Y. Lai

The Brazilian Journal of Medical and Biological Research is partially financed by

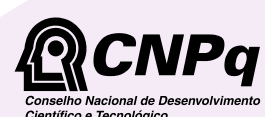

da Ciência e Tecnologia

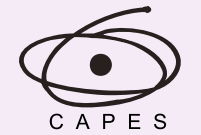

Ministério da Educação

Institutional Sponsors
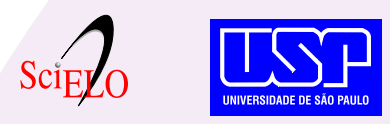

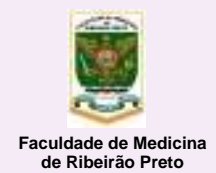

de Ribeirão Preto

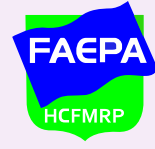

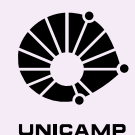

UNICAMP

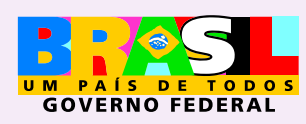

DTAPESP

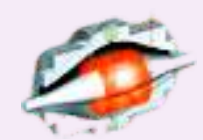

Ф SHIMADZU

Explore High - Performance MS Orbitrap Technology
In Proteomics \& Metabolomics

$\underset{\text { analitica }}{\text { analiticaweb.com.br }}$ SCIENTIFIC 


\title{
Testosterone therapy delays cardiomyocyte aging via an androgen receptor-independent pathway
}

\author{
L. Zhang ${ }^{1}$, S.Z. Wu${ }^{1}$, Y.J. Ruan ${ }^{2}$, L. Hong ${ }^{1}$, X.W. Xing ${ }^{3}$ and W.Y. Lai ${ }^{4}$ \\ ${ }^{1}$ Department of Cardiology, Nangfang Hospital, Southern Medical University, Guangzhou, Guangdong, China \\ 2Department of Cardiology, Guangzhou General Hospital, Guangzhou Military Area Command of Chinese PLA, \\ Guangzhou, Guangdong, China \\ ${ }^{3}$ Laboratory of Cardiovascular Diseases, The First Affiliated Hospital of Guangzhou Medical College, \\ Guangzhou, Guangdong, China \\ ${ }^{4}$ Laboratory of Cardiovascular Diseases, Nanfang Hospital, Southern Medical University, \\ Guangzhou, Guangdong, China
}

\begin{abstract}
The testicular feminized (Tfm) mouse carries a nonfunctional androgen receptor (AR) and reduced circulating testosterone levels. We used $\mathrm{Tfm}$ and castrated mice to determine whether testosterone modulates markers of aging in cardiomyocytes via its classic AR-dependent pathway or conversion to estradiol. Male littermates and Tfm mice were divided into 6 experimental groups. Castrated littermates (group 1) and sham-operated Tfm mice (group 2, N = 8 each) received testosterone. Shamoperated Tfm mice received testosterone in combination with the aromatase inhibitor anastrazole (group 3, N = 7). Castrated littermates (group 4) and sham-operated untreated Tfm mice (group 5) were used as controls ( $\mathrm{N}=8$ and 7 , respectively). An additional control group (group 6) consisted of age-matched non-castrated littermates $(\mathrm{N}=8)$. Cardiomyocytes were isolated from the left ventricle, telomere length was measured by quantitative PCR and expression of $p 16^{\text {INK4a, }}$, retinoblastoma (Rb) and p53 proteins was detected by Western blot 3 months after treatment. Compared with group 6, telomere length was short $(P<0.01)$ and expression of $p 16^{I N K 4 \alpha}, R b$ and p53 proteins was significantly $(P<0.05)$ up-regulated in groups 4 and 5 . These changes were improved to nearly normal levels in groups 1 and 2 (telomere length $=0.78 \pm 0.05$ and $0.80 \pm 0.08 ; p 16^{\text {INK4 } \alpha=}$ $0.13 \pm 0.03$ and $0.15 \pm 0.04 ; \mathrm{Rb}=0.45 \pm 0.05$ and $0.39 \pm 0.06 ; \mathrm{p} 53=0.16 \pm 0.04$ and $0.13 \pm 0.03$ ), but did not differ between these two groups. These improvements were partly inhibited in group 3 compared with group 2 (telomere length $=0.65 \pm 0.08$ vs $0.80 \pm 0.08, \mathrm{P}=0.021 ; \mathrm{p} 16^{\mathrm{INK} 4 \alpha}=0.28 \pm 0.05$ vs $0.15 \pm 0.04, \mathrm{P}=0.047 ; \mathrm{Rb}=0.60 \pm 0.06$ vs $0.39 \pm 0.06, \mathrm{P}<0.01 ; \mathrm{p} 53=$ $0.34 \pm 0.06$ vs $0.13 \pm 0.03, P=0.004)$. In conclusion, testosterone deficiency contributes to cardiomyocyte aging. Physiological testosterone can delay cardiomyocyte aging via an AR-independent pathway and in part by conversion to estradiol.
\end{abstract}

Key words: Aging; Testosterone; Cardiomyocyte; Androgen receptor; Estradiol; Tfm mice

\section{Introduction}

Aging per se is a risk factor for reduced cardiac function and heart disease, even when adjusted for conventional cardiovascular risk factors. With aging, cardiac function is organically and cellularly impaired. Cardiomyocytes, the major components of the contractile apparatus, undergo a number of physiological and morphological changes with age, and these changes are thought to contribute to reduced cardiac function and heart disease (1). It is likely that modulation of cardiomyocyte aging changes the threshold for the manifestation of signs and symptoms of heart disease.

Testosterone is the major circulating androgen and its level declines with age in men (2). It is known that testosterone replacement therapy restores many of the adverse pathophysiological events, which occur in androgen deficiency (3). Several studies have suggested a relationship between testosterone and brain aging with an effect on cognition (4-6). Also, reduced androgen levels have been associated with aging-related cardiovascular diseases and testosterone replacement therapy may have some benefi-

Correspondence: S.Z. Wu, Department of Cardiology, Nanfang Hospital, Southern Medical University, Guangzhou, Guangdong, 510515, China. Fax: +86-2061-642-151. E-mail: wusaizhu@126.com

Received February 8, 2011. Accepted September 16, 2011. Available online September 30, 2011. Published November $14,2011$. 
cial effects on cardiovascular function (7). Furthermore, in experimental rats with low testosterone levels, physiological testosterone therapy can improve reduced cardiac functional capacity, probably by inhibition of tumor necrosis factor alpha (TNF-a) (8), which is a pro-inflammatory cytokine closely linked to the aging process (1). These data have led to the hypothesis that testosterone has a positive impact on the aging process of the cardiovascular system.

Testosterone exerts a variety of anabolic and androgenic effects on many organs and most of these actions are mediated by the nuclear androgen receptor (AR) (9). The AR gene is also expressed in mammalian and primate cardiomyocytes, suggesting that androgens may play a role in the heart $(10,11)$. Golden et al. (11) reported that gonadectomy slowed the contractile velocity by altering myosin heavy chain composition in isolated cardiomyocytes of adult male rats. Moreover, in castrated rats testosterone supplementation reversed the decline in myosin heavy chain content to values seen in sham-operated controls. The same investigators reported that testosterone regulated the functional expression of L-type calcium channel mRNA levels in isolated rat cardiomyocytes and this effect was mediated by the AR (12). In addition to the AR pathway, the beneficial effect of long-term testosterone on cardiomyocytes may have been due to the conversion to estradiol by aromatase activity $(13,14)$. Although testosterone may be of pathophysiological importance to the heart, there are no published studies, which demonstrate the role of testosterone and AR as modulators of aging in cardiomyocytes.

The testicular feminized ( $\mathrm{Tfm}$ ) mouse exhibits an Xlinked, single base-pair deletion in the gene encoding the $A R$. This deletion results in premature termination of $A R$ protein synthesis, with the occurrence of a nonfunctional AR $(15,16)$. In addition, circulating levels of testosterone are reduced in the Tfm mouse, reportedly being 10-fold lower compared to male littermates (16). Cellular aging is characterized by an irreversible cell cycle arrest and loss of specialized functions. Telomere length, p16 INK4a and p53 expression are plotted as a function of age (17). Cellular aging is also modulated by Rb. p16 $16^{\mathrm{INK} 4 \alpha}$ inhibits cyclin-dependent kinases and maintains $\mathrm{Rb}$ in its unphosphorylated, growth-suppressive state (17). Therefore, in the present study, we investigated whether testosterone deficiency and/or the absence of a functional AR are associated with the changes of telomere length and of the expression of the above-mentioned genes in murine cardiomyocytes. Furthermore, we determined whether physiological testosterone therapy modulates cardiomyocyte aging via the AR-dependent pathway or conversion to estradiol in Tfm and castrated male mice.

\section{Material and Methods}

\section{Experimental animals and design}

All experimental procedures and protocols used in this investigation were reviewed and approved by the Ethics Committee of Nanfang Hospital, Southern Medical University. Male littermates and Tfm mice were bred from mice purchased from the Model Animal Research Center of

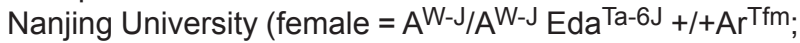
male $=A$ W-J $/ A^{W-J}$ EdaTa-6J $+/ Y$ ). The gender of Tfm mice was identified by PCR. Mice were kept under standard temperature $\left(20-26^{\circ} \mathrm{C}\right)$, humidity $(40-70 \%)$, and illumination (12-h light/12-h dark cycle, lights on at 8:00 h).

At 8 weeks of age, male littermates and Tfm mice underwent surgical castration or sham operation, respectively. Four weeks after surgery, castrated mice were treated with $(\mathrm{N}=8)$ or not $(\mathrm{N}=8)$ with testosterone propionate (Guangzhou Mingxing Pharmaceutical Company, China), while sham-operated Tfm mice were also treated $(\mathrm{N}=8)$ or not $(\mathrm{N}=7)$ with testosterone propionate. Another 7 shamoperated $\mathrm{Tfm}$ mice were treated with testosterone propionate in combination with $10 \mathrm{mg} \cdot \mathrm{kg}^{-1} \cdot \mathrm{day}^{-1}$ of the aromatase inhibitor anastrazole (AstraZeneca, UK) in drinking water (18). Testosterone was injected intramuscularly at $3 \mathrm{mg} / \mathrm{kg}$, diluted in sesame oil, once during each 72-h period for 3 months. Age-matched 24-week-old nonsurgical littermates were used as controls $(\mathrm{N}=8)$. Before these manipulations, pharmacokinetic determination of physiological testosterone was performed.

\section{Pharmacokinetic determination of physiological testosterone}

To establish and maintain a dosing regimen of testosterone at physiological concentrations, we first had to determine the appropriate volume and frequency of administration of $25 \mathrm{mg} / \mathrm{mL}$ testosterone propionate. At 8 weeks of age, male littermate mice $(\mathrm{N}=36)$ underwent surgical castration and were allowed to recover in individual cages for 4 weeks. Next, 12-week-old mice received a single 3 $\mathrm{mg} / \mathrm{kg}$ intramuscular injection of testosterone propionate (the human replacement dose of testosterone propionate is $0.35 \mathrm{mg} / \mathrm{kg}$ administered 2-3 times per week according to manufacturer instructions. Mice were sacrificed at 30 min, and at 1, 2, 4, 8, 16, 24, 32, 48, and $72 \mathrm{~h}$ after injection, and testosterone concentrations were measured in duplicate (ELISA kits, R\&D Systems, Inc., USA). To ensure reproducibility, 18 additional castrated littermates received a second-cycle injection (double administration) beginning $72 \mathrm{~h}$ after the first and were sacrificed at 1, 2, 4, 8, 24, and $72 \mathrm{~h}$ after the second injection. At the same time, in order to determine normal testosterone concentrations, 9 non-castrated male mice were sacrificed at 0:00, 8:00, and 16:00 $\mathrm{h}$.

\section{Isolation of cardiomyocytes}

Left ventricular myocytes were enzymatically isolated from 39 male mice as described previously $(17,19)$. Briefly, hearts were quickly removed and connected to a plastic cannula for retrograde perfusion through the aorta. The solutions 
were supplements of modified commercial minimal essential medium (MEM) Eagle-Joklik. HEPES-MEM contained 117 $\mathrm{mM} \mathrm{NaCl}, 5.7 \mathrm{mM} \mathrm{KCl}, 4.4 \mathrm{mM} \mathrm{NaHCO}_{3}, 1.5 \mathrm{mM} \mathrm{KH}_{2} \mathrm{PO}_{4}$, $17 \mathrm{mM} \mathrm{MgCl}_{2}, 21.1 \mathrm{mM}$ HEPES, and $11.7 \mathrm{mM}$ glucose with amino acids and vitamins, $2 \mathrm{mM}$ L-glutamine, and 21 $\mathrm{mU} / \mathrm{mL}$ insulin; $\mathrm{pH}$ was adjusted to 7.2 with $\mathrm{NaOH}$. The washing solution was HEPES-MEM with the addition of 0.5 mM EGTA. The resuspension medium was HEPES-MEM supplemented with $0.5 \%$ bovine serum albumin (BSA) and $0.3 \mathrm{mM} \mathrm{CaCl}_{2}$. The cell isolation procedure consisted of 3 main steps: 1) for low-calcium perfusion, blood washout in the presence of EGTA was performed for about $10 \mathrm{~min}$, and $0.05 \%$ collagenase (selected type I, Worthington Biochemical Corp., USA) perfusion of the myocardium was carried out at $37^{\circ} \mathrm{C}$ with HEPES-MEM gassed with $85 \% \mathrm{O}_{2}, 15 \%$ $N_{2}$. 2) After the heart was removed from the cannula, the left ventricle was cut into small pieces and subsequently shaken in resuspension medium at $37^{\circ} \mathrm{C}$. Supernatant cell suspensions were washed and resuspended in resuspension medium. 3) Intact cells were concentrated by centrifugation. This procedure was repeated 4-5 times.

\section{Quantitative PCR assay}

Quantitative PCR assay was used to measure telomere $(T)$ signals and single-copy gene signals ( $S, \beta$-globin gene) in experimental DNA samples extracted from isolated cardiomyocytes. The relative $\mathrm{T} / \mathrm{S}$ ratios indicated relative telomere length $(20,21)$.

The final reaction system in the quantitative PCR consisted of a final volume of $20 \mu \mathrm{L}$ per reaction, including 10 $\mu \mathrm{L} 2 X$ AllinOne $^{\mathrm{TM}}$ quantitative-PCR Mix (SYBR Green I, GeneCopoeia, USA), $2 \mu \mathrm{L}$ T primer pair telg and telc (final concentrations of $900 \mathrm{nM}$ each), or $2 \mu \mathrm{L} S$ primer pair hbgu and hbgd (final concentrations $200 \mathrm{nM}$ each), and 2 $\mu \mathrm{L}$ of each experimental DNA sample (20 ng DNA). Five concentrations of a reference DNA sample (genomic DNA extracted from any individual mouse DNA sample) ranging from 0.16 to $100 \mathrm{ng} / \mathrm{\mu L}$ were prepared by serial dilution to provide data for the generation of the standard curves used for relative quantitation.

The thermal cycling profile consisted of $10 \mathrm{~min}$ at $95^{\circ} \mathrm{C}$, followed by 2 cycles of $10 \mathrm{~s}$ at $95^{\circ} \mathrm{C}, 20 \mathrm{~s}$ at $49^{\circ} \mathrm{C}$, and 15 s at $72^{\circ} \mathrm{C}$, and 40 cycles of $10 \mathrm{~s}$ at $94^{\circ} \mathrm{C}, 20 \mathrm{~s}$ at $60^{\circ} \mathrm{C}$, and $15 \mathrm{~s}$ at $72^{\circ} \mathrm{C}$. After thermal cycling, the Bio-Rad (USA) iQ5 2.0 Standard Edition Optical System Software was used to generate two standard curves and to read cycle threshold $(\mathrm{Ct})$ values of $\mathrm{T}$ and $\mathrm{S}$ signals.

Tand S primers were as follows: telg, ACACTAAGGTTTG GGTTTGGGTTTGGGTTTGGGTTAGTGT and telc, TGTT AGGTATCCCTATCCCTATCCCTATCCCTATCCCTAACA. hbgu, CTGCCCTGGCTCACAAGTAC, and hbgd, AGATG CCCAAAGGTCTTCATC.

\section{Western blotting \\ Freshly isolated cardiomyocytes were lysed in $250 \mu \mathrm{L}$}

lysis buffer (50 mM Tris-HCl, pH 7.5, 5 mM EDTA, 250 $\mathrm{mM} \mathrm{NaCl}$, and $0.1 \%$ Triton $\mathrm{X}-100$ ) containing the following protease inhibitors: $2 \mathrm{mM}$ PMSF, $1 \mu \mathrm{g} / \mathrm{mL}$ aprotinin, $5 \mathrm{mM}$ DTT, and $1 \mathrm{mM} \mathrm{Na}_{3} \mathrm{VO}_{4}$. Myocyte lysates were centrifuged at $6700 \mathrm{~g}$ for $10 \mathrm{~min}$ (19). Forty micrograms protein was separated by $10-15 \%$ SDS-PAGE and electroblotted onto polyvinylidene difluoride membranes (Bio-Rad). After blocking with $5 \%$ BSA for $1 \mathrm{~h}$, the membranes were incubated overnight with primary antibody dilution buffer at $4^{\circ} \mathrm{C}$. Anti-p16 ${ }^{I N K 4 \alpha}$ (F-12, Santa Cruz Biotechnology, Inc., USA), anti-p53 (FL-393, Santa Cruz), and anti-unphosphorylated $\mathrm{Rb}$ (Wuhan Boster Co., China) were used. HRP-conjugated goat anti-mouse IgG and goat anti-rabbit (Bio-Rad) served as the secondary antibodies. The membranes were briefly incubated with ECL detection reagent (Thermo, USA) to visualize the proteins and exposed to X-ray film. $\beta$-actin (Wuhan Boster Co.) was used as an internal control for all the Western blotting procedures. The Western blotting data presented in this study were from at least 3 independent experiments.

\section{Measurement of testosterone concentration}

At the time of measurements and the end of the study, all animals were anesthetized and blood was collected without anticoagulant from the retroorbital venous plexus. Samples were centrifuged at $1400 \mathrm{~g}$ for $10 \mathrm{~min}$ and serum was collected and stored at $-20^{\circ} \mathrm{C}$ until assay. Total testosterone levels were measured in duplicate using commercially available ELISA kits (R\&D Systems, Inc.). Interassay variation was $2.9-4.0 \%$ and intra-assay variation was $5.6-6.8 \%$.

\section{Statistical analysis}

SPSS Version 13.0 (Statistical Software for Social Sciences, USA) was used for statistical analysis. Data are reported as means $\pm S D$ and were analyzed by one-way ANOVA, with equal variances assumed with the least significant difference (LSD) test and equal variances not assumed with Dunnett's T3 multiple comparisons. The level of significance was set at $\mathrm{P}<0.05$.

\section{Results}

\section{Determination of a dose regimen to reach physiological testosterone levels in castrated mice}

The normal range of testosterone concentrations was 12.6 to $28.7 \mathrm{nM}$. After castration, baseline levels of serum testosterone were about $6 \%$ of normal levels. The levels rose significantly from baseline after intramuscular injection of $3 \mathrm{mg} / \mathrm{kg}$ testosterone at $30 \mathrm{~min}$, reached a peak at $2 \mathrm{~h}$, and remained within the normal range between 14 and 50 h (Figure 1). The mean area under the curve (AUC) for the first 72-h period was $20.6 \mathrm{nM}$ and the mean AUC for the second 72-h period was $22.7 \mathrm{nM}$. Pharmacokinetics showed that there was no statistical difference for the peak time, AUC, or testosterone concentrations between single 
and double administrations. Furthermore, after single and double administrations, the mean AUC were all within the normal range. These results agree with those of Nettleship et al. (18) and indicate a good reproducibility of the pharmacokinetic profile and that a sufficient physiological replacement therapy would be $3 \mathrm{mg} \cdot \mathrm{kg}^{-1} .72 \mathrm{~h}^{-1}$ intramuscular testosterone propionate in castrated male mice.

\section{Telomere length}

The $\mathrm{Ct}$ values of $\mathrm{T}$ and $\mathrm{S}$ were calculated with their independent standard curves. The relative T/S ratios of castrated and sham-operated Tfm mice did not differ significantly (Figure 2, columns 2 and 4, respectively). These, however, were significantly lower than those observed in control mice (column 1, both $\mathrm{P}<0.01$ ). After testosterone therapy, an increase in the relative $\mathrm{T} / \mathrm{S}$ ratios was detected in castrated (column 3) and sham-operated Tfm mice (column 5) compared with their untreated controls (columns 2 and 4 , both $\mathrm{P}<0.01$ ). Moreover, the values for testosteronetreated castrated and sham-operated Tfm mice did not differ significantly $(P>0.05)$. The relative $T / S$ ratios were significantly lower in sham-operated $\mathrm{Tfm}$ mice receiving testosterone in combination with anastrazole (column 6) compared with those receiving testosterone alone (column $5, P=0.021)$. However, the values were still higher than those of untreated Tfm mice (column 4, P = 0.044).

\section{Expression of $\mathrm{p} 16^{\mathrm{INK} 4 \alpha}$ and Rb proteins}

As shown in Figure 3, expression of $\mathrm{p} 16^{\mathrm{INK} 4 \alpha}$ and $\mathrm{Rb}$ proteins was low in control mice. The expression levels, however, were significantly higher in both castrated and sham-operated Tfm mice than in control mice ( $p 16^{\mathrm{INK} 4 \alpha}$ $=$ both $\mathrm{P}<0.05$. Rb = both $\mathrm{P}<0.01$ ). There were no significant differences between the two experimental groups (both $P>0.05$ ). After testosterone treatment, the levels of $\mathrm{p} 16^{\mathrm{INK} 4 \alpha}$ and $\mathrm{Rb}$ proteins were down-regulated in both castrated and sham-operated Tfm mice compared with untreated mice $\left(p 16^{I N K 4 \alpha}=\right.$ both $P<0.05$. Rb $=$ both $P<$ $0.01)$. Moreover, the values did not differ significantly between testosterone-treated castrated and sham-operated Tfm mice (both $P>0.05$ ). Expression of $\mathrm{p} 16^{\mathrm{INK} 4 \alpha}$ and Rb proteins was significantly higher in sham-operated Tfm mice receiving testosterone in combination with anastrazole compared with those receiving testosterone alone ( $\left.p 16^{\mathrm{INK} 4 \alpha}, \mathrm{P}=0.047 ; \mathrm{Rb}, \mathrm{P}<0.001\right)$. However, the levels

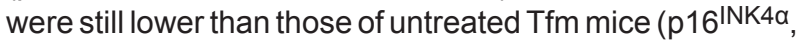
$\mathrm{P}=0.045 ; \mathrm{Rb}, \mathrm{P}=0.008$ ).

\section{Expression of p53 protein}

Expression of p53 protein did not differ significantly $(P$ $>0.05$ ) between castrated (Figure 4, column 2) and shamoperated Tfm mice (column 3). The levels, however, were significantly higher than those observed in control mice (column 1, both $\mathrm{P}<0.01$ ). After testosterone treatment, a down-regulation of p53 protein expression was detected

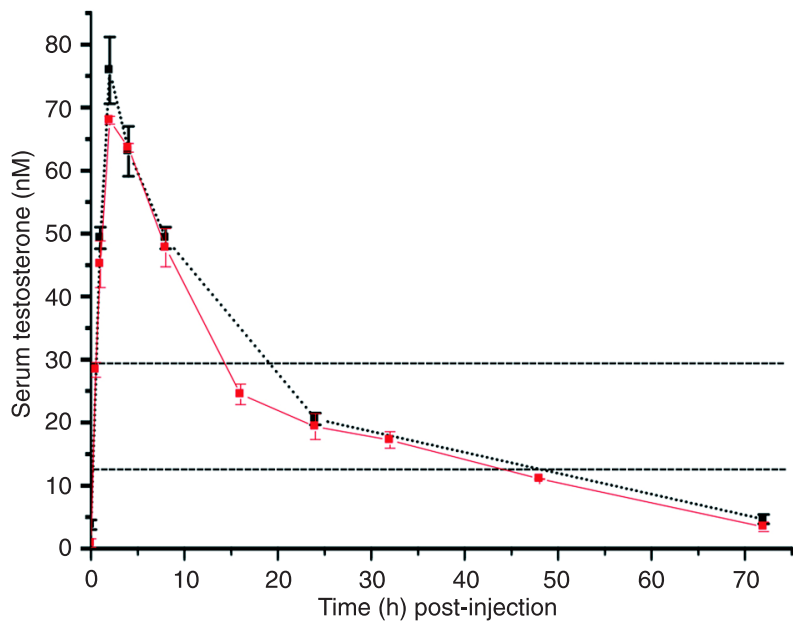

Figure 1. Pharmacokinetic curves of the single and double 72-h period injection of testosterone propionate in castrated littermates. Castrated mice received a single $3 \mathrm{mg} / \mathrm{kg}$ intramuscular injection of $25 \mathrm{mg} / \mathrm{mL}$ testosterone ( $\mathrm{N}=36$, red solid line). An additional $3 \mathrm{mg} / \mathrm{kg}$ intramuscular injection of $25 \mathrm{mg} / \mathrm{mL}$ testosterone was administered at $72 \mathrm{~h}$ after the first injection $(\mathrm{N}=18$, black broken line). Mice were sacrificed at the times indicated after injection and serum testosterone concentrations were measured. There was no statistically significant difference in peak time, mean area under the curve, or testosterone concentrations between single and double administrations. The area between the dashed parallel lines indicates the physiological range of testosterone (12.6 to $28.7 \mathrm{nM}$ ).

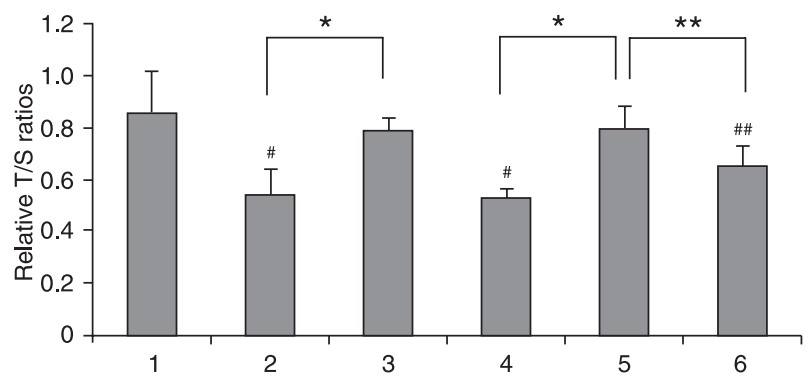

Figure 2. Quantitative PCR assay of relative telomere length in cardiomyocytes expressed as the relative T/S ratios. Columns: 1, control group; 2, castrated group; 3, castrated + testosterone group; 4, sham-operated Tfm group; 5 , sham-operated Tfm + testosterone group; 6, sham-operated Tfm + testosterone + anastrazole group. Data are reported as means $\pm \mathrm{SD}$. ${ }^{\# P}<0.01$ compared to the control group; $\mathrm{\#} P<0.05$ compared to the shamoperated Tfm group; ${ }^{*} \mathrm{P}<0.01 ;{ }^{* *} \mathrm{P}<0.05$ (ANOVA + Dunnett T3 test). There were no significant differences between castrated and sham-operated Tfm mice or between testosterone-treated castrated and sham-operated $\mathrm{Tfm}$ mice. $\mathrm{Tfm}=$ testicular feminized mouse. 
A

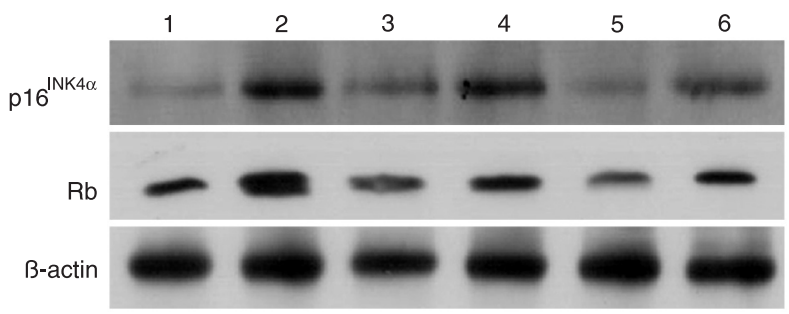

B

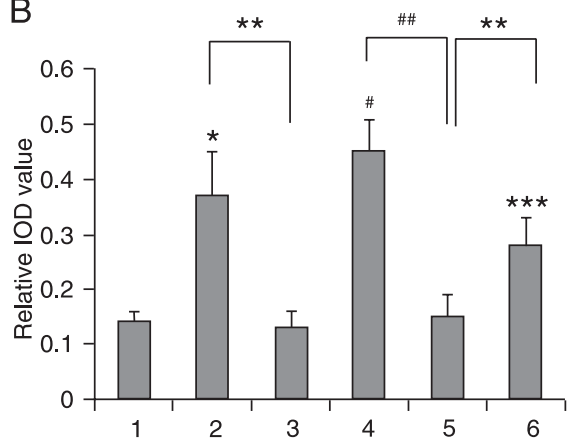

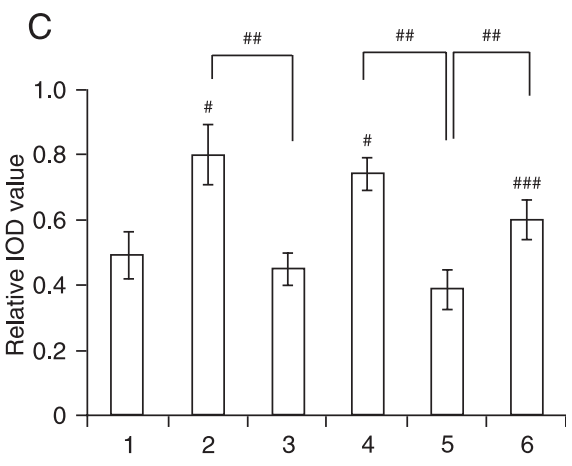

Figure 3. Western blot analysis of $\mathrm{p} 16^{\mathrm{INK} 4 \alpha}$ and $\mathrm{Rb}$ proteins with $\beta$-actin as an internal control $(A)$. Densitometric analysis of $\mathrm{p} 16^{\mathrm{INK} 4 \alpha}$ protein $(B)$ and Rb protein $(C)$. Columns: 1 , control group; 2, castrated group; 3 , castrated + testosterone group; 4, sham-operated Tfm group; 5, sham-operated Tfm + testosterone group; 6 , sham-operated $\mathrm{Tfm}+$ testosterone + anastrazole group. Data are reported as means $\pm \mathrm{SD} .{ }^{*} \mathrm{P}<0.05$ compared to the control group; \#P < 0.01 compared to the control group; ${ }^{* * *} \mathrm{P}<0.05$ compared to the sham-operated Tfm group; \#\#P < 0.01 compared to the sham-operated Tfm group; ${ }^{* *} \mathrm{P}<0.05$; \#\# $\mathrm{P}<0.01$ (ANOVA + LSD test). There were no significant differences between castrated and sham-operated Tfm mice or between testosterone-treated castrated and sham-operated $\mathrm{Tfm}$ mice. $\mathrm{Tfm}=$ testicular feminized mouse; IOD = integrated optical density.
A

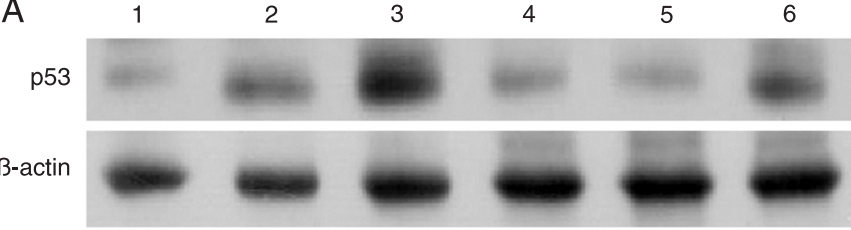

B

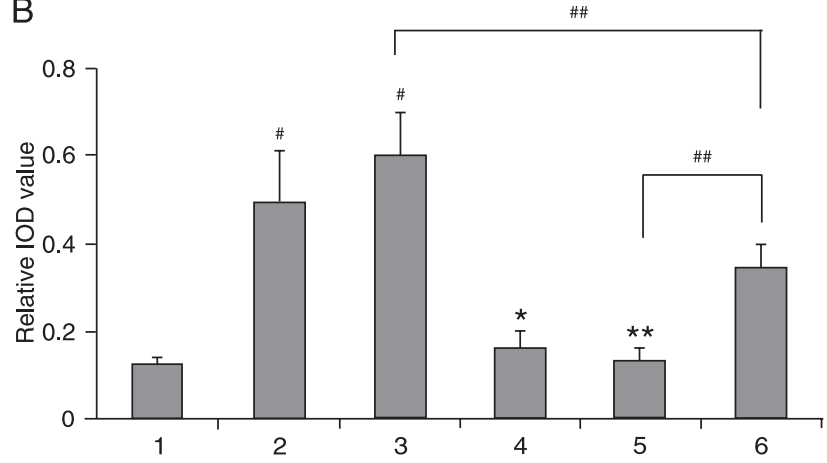

Figure 4. Western blot analysis of p53 protein with $\beta$-actin as an internal control $(A)$. Densitometric analysis of p53 protein (B). Columns: 1, control group; 2, castrated group; 3, sham-operated Tfm group; 4, castrated + testosterone group; 5 , sham-operated $\mathrm{Tfm}+$ testosterone group; 6, sham-operated Tfm + testosterone + anastrazole group. Data are reported as means $\pm S D$. ${ }^{\#} P<0.01$ compared to control group; ${ }^{*} P$ $<0.01$ compared to castrated group; ${ }^{* *} \mathrm{P}<0.01$ compared to sham-operated Tfm group; \#\#P < 0.01 (ANOVA + LSD test). There were no significant differences between castrated and sham-operated Tfm mice or between testosterone-treated castrated and sham-operated Tfm mice. $\mathrm{Tfm}=$ testicular feminized mouse; IOD = integrated optical density. in both castrated (column 4) and sham-operated Tfm mice (column 5) compared with untreated mice (columns 2 and 3 , both $\mathrm{P}<0.01$ ). Moreover, the values did not differ significantly between testosterone-treated castrated and sham-operated Tfm mice $(P>0.05)$. Compared with sham-operated Tfm mice treated with testosterone (column 5), expression of p53 protein was significantly higher in sham-operated Tfm mice treated with testosterone in combination with anastrazole (column 6, $\mathrm{P}=0.004$ ). However, the levels were still lower than those of untreated Tfm mice (column 3, $\mathrm{P}=0.001$ ).

\section{Discussion}

In the present study, we observed that testosterone concentrations of castrated mice were approximately $6 \%$ of those of control mice. The values reached about $9 \%$ in sham-operated Tfm mice (data not shown), consistent with the study of Jones et al. (16). Left ventricular myocytes from castrated and sham-operated Tfm mice had short telomere length and increased expression of $\mathrm{p} 16^{\mathrm{INK} 4 \alpha}, \mathrm{Rb}$ and p53 proteins compared with control. Moreover, these parameters did not differ significantly between castrated and sham-operated Tfm mice. These observations provide evidence that testosterone deficiency contributes to cardiomyocyte aging. Furthermore, we observed amelioration of cardiomyocyte aging with long-term physiological testosterone therapy 
as indicated by increased telomere length and downregulation of expression of $\mathrm{p} 16^{\mathrm{INK} 4 \alpha}, \mathrm{Rb}$ and $\mathrm{p} 53$ proteins. Surprisingly, their levels were statistically similar to those of control mice.

Senescent cardiomyocytes are characterized by an irreversible cell cycle arrest, which is mediated and indicated by an up-regulation of $\mathrm{p} 16^{\mathrm{INK} 4 \alpha}$ and $\mathrm{p} 53$, and show a reduction in telomere length (1). Kajstura et al. (22) reported that telomeric shortening in myocytes and the fraction of p16 ${ }^{\mathrm{INK} 4 \alpha_{-}}$-positive myocytes increased with age. Another study demonstrated a $39 \%$ reduction in mean telomere length in human aged hearts. Cardiomyocytes with telomeres equal to or shorter than $2.5 \mathrm{kbp}$ were $\mathrm{p} 16^{\mathrm{INK} 4 \mathrm{a}_{-} \text {positive }}$ (23). Torella et al. (17) found that the expression of $\mathrm{p} 16^{\mathrm{INK} 4 a}$ and p53 increased with age in cardiomyocytes of wide-type (WT) mice. Hypophosphorylated Rb was predominant in aging WT cardiomyocytes, reflecting the up-regulation of $\mathrm{p} 16^{\mathrm{INK} 4 \alpha}$. Cells with shorter telomeres were $\mathrm{p} 16^{\mathrm{INK} 4 \alpha_{-}}$and p53-positive. Compared to young cells (4 months), telomere length was reduced by approximately $35 \%$ in old WT cardiomyocytes (20-22 months). Similarly, the mRNA levels of p16 ${ }^{\mathrm{INK} 4 a}$ and acetylated p53 were increased in aged rat cardiomyocytes in the study by Maejima et al. (24). In other aging animal models, telomere shortening coincides with increased expression of p53 in isolated cardiomyocyte nuclei (25).

As mentioned earlier, we observed a protective role of testosterone therapy against the development of cardiomyocyte aging. Similarly, administration of testosterone has been shown to improve brain aging in older male C57BL/6 mice and in young castrated mice (6). Testosterone also protects skeletal muscle cells and neurons from cell death $(26,27)$. Lu et al. (28) showed that androgen down-regulated the expression of the cyclin-dependent kinase inhibitor p16 ${ }^{\text {INK4a }}$ gene in LNCaP-FGC cells. In a previous study conducted by Gregory et al. (29), the hypophosphorylated form of $\mathrm{Rb}$ was down-regulated by testosterone propionate treatment in castrated mice. Zhang et al. (30) found that expression of p53 mRNA was decreased in rat prostate glands after testosterone replacement therapy. These data are consistent with the observations of the present study. The amelioration of cardiomyocyte aging did not differ significantly between castrated and sham-operated $\mathrm{Tfm}$ mice after physiological testosterone therapy. Due to the following observations, we conclude that the positive

\section{References}

1. Bernhard D, Laufer G. The aging cardiomyocyte: a minireview. Gerontology 2008; 54: 24-31.

2. Araujo AB, O'Donnell AB, Brambilla DJ, Simpson WB, Longcope $C$, Matsumoto AM, et al. Prevalence and incidence of androgen deficiency in middle-aged and older men: estimates from the Massachusetts Male Aging Study. J Clin effects of testosterone on cardiomyocyte aging occur via an AR-independent pathway: a) Tfm mice carry nonfunctional $A R$ and still respond to testosterone, and b) castrated mice with functional AR show signs of cardiomyocyte aging that can be cured with testosterone.

In fact, local conversion of testosterone to estradiol via aromatase has been proposed to mediate the potentially beneficial effects of testosterone. After conversion, estradiol elicits direct cellular effects by activation of estrogen receptor $\alpha(E R \alpha)$ and $E R \beta(31,32)$. In the present study, increased telomere length and down-regulation of expression of $\mathrm{p} 16^{\mathrm{INK} 4 \alpha}, \mathrm{Rb}$ and $\mathrm{p} 53$ proteins in sham-operated $\mathrm{Tfm}$ mice receiving testosterone therapy were significantly inhibited by co-treatment with the aromatase inhibitor. The degree of cardiomyocyte aging in anastrazole-treated Tfm mice, however, was still lower than in sham-operated Tfm mice. These data demonstrate that physiological testosterone levels ameliorate cardiomyocyte aging mediated in part by aromatization to estradiol in cardiac myocytes. Michels et al. (13) reported that the long-term effect of testosterone on single T-type calcium channel was mediated in part via the estrogen pathway in neonatal rat cardiomyocytes. Co-incubation of rat cardiac myocytes with testosterone and the specific aromatase inhibitor showed an inhibition of estrogen-responsive element activation but this was not observed in cells incubated with testosterone alone, thereby implicating conversion to estradiol as the mechanism of action of testosterone in cardiomyocytes (14).

Our results support the view that testosterone deficiency contributes to cardiomyocyte aging in Tfm and castrated male mice. We demonstrated the beneficial effect of physiological levels of testosterone on cardiomyocyte aging, an action that is independent of the classical AR and is mediated in part by conversion to estradiol. Given the increasing incidence and prevalence of heart disease with aging, it will be useful to study the effect and mechanism of action of testosterone on cardiomyocyte aging. However, further investigations are needed before these results can be extrapolated from mice to humans.

\section{Acknowledgments}

Research supported by the National Key Fundamental Research and Development Project (\#2007CB507404).
Endocrinol Metab 2004; 89: 5920-5926.

3. Bain J. Testosterone and the aging male: to treat or not to treat? Maturitas 2010; 66: 16-22.

4. Muller M, Aleman A, Grobbee DE, de Haan EH, van der Schouw YT. Endogenous sex hormone levels and cognitive function in aging men: is there an optimal level? Neurology 
2005; 64: 866-871

5. Kritzer MF, McLaughlin PJ, Smirlis T, Robinson JK. Gonadectomy impairs T-maze acquisition in adult male rats. Horm Behav 2001; 39: 167-174.

6. Frye CA, Edinger K, Sumida K. Androgen administration to aged male mice increases anti-anxiety behavior and enhances cognitive performance. Neuropsychopharmacology 2008; 33: 1049-1061.

7. Gooren LJ. Androgens and male aging: Current evidence of safety and efficacy. Asian J Androl 2010; 12: 136-151.

8. Li ZB, Wang J, Wang JX, Chen XM, Jiang SS. [Testosterone therapy improves cardiac function of male rats with right heart failure]. Zhonghua Nan Ke Xue 2009; 15: 994-1000.

9. Wilbert DM, Griffin JE, Wilson JD. Characterization of the cytosol androgen receptor of the human prostate. J Clin Endocrinol Metab 1983; 56: 113-120.

10. Marsh JD, Lehmann MH, Ritchie RH, Gwathmey JK, Green GE, Schiebinger RJ. Androgen receptors mediate hypertrophy in cardiac myocytes. Circulation 1998; 98: 256-261.

11. Golden KL, Marsh JD, Jiang Y, Moulden J. Gonadectomy alters myosin heavy chain composition in isolated cardiac myocytes. Endocrine 2004; 24: 137-140.

12. Golden KL, Marsh JD, Jiang Y. Testosterone regulates mRNA levels of calcium regulatory proteins in cardiac myocytes. Horm Metab Res 2004; 36: 197-202.

13. Michels G, Er F, Eicks M, Herzig S, Hoppe UC. Long-term and immediate effect of testosterone on single T-type calcium channel in neonatal rat cardiomyocytes. Endocrinology 2006; 147: 5160-5169.

14. Grohe C, Kahlert S, Lobbert K, Vetter H. Expression of oestrogen receptor alpha and beta in rat heart: role of local oestrogen synthesis. J Endocrinol 1998; 156: R1-R7.

15. He WW, Kumar MV, Tindall DJ. A frame-shift mutation in the androgen receptor gene causes complete androgen insensitivity in the testicular-feminized mouse. Nucleic Acids Res 1991; 19: 2373-2378.

16. Jones RD, Pugh PJ, Hall J, Channer KS, Jones TH. Altered circulating hormone levels, endothelial function and vascular reactivity in the testicular feminised mouse. Eur J Endocrinol 2003; 148: 111-120.

17. Torella D, Rota M, Nurzynska D, Musso E, Monsen A, Shiraishi I, et al. Cardiac stem cell and myocyte aging, heart failure, and insulin-like growth factor-1 overexpression. Circ Res 2004; 94: 514-524.

18. Nettleship JE, Jones TH, Channer KS, Jones RD. Physiological testosterone replacement therapy attenuates fatty streak formation and improves high-density lipoprotein cholesterol in the Tfm mouse: an effect that is independent of the classic androgen receptor. Circulation 2007; 116: 2427-2434.

19. Leri A, Liu Y, Wang X, Kajstura J, Malhotra A, Meggs LG, et al. Overexpression of insulin-like growth factor- 1 attenuates the myocyte renin-angiotensin system in transgenic mice. Circ Res 1999; 84: 752-762.

20. Cawthon RM. Telomere length measurement by a novel monochrome multiplex quantitative PCR method. Nucleic Acids Res 2009; 37: e21.

21. Fehrer C, Voglauer R, Wieser M, Pfister G, Brunauer R, Cioca $D$, et al. Techniques in gerontology: cell lines as standards for telomere length and telomerase activity assessment. Exp Gerontol 2006; 41: 648-651.

22. Kajstura J, Pertoldi B, Leri A, Beltrami CA, Deptala A, Darzynkiewicz Z, et al. Telomere shortening is an in vivo marker of myocyte replication and aging. Am J Pathol 2000; 156: 813-819.

23. Chimenti C, Kajstura J, Torella D, Urbanek K, Heleniak H, Colussi $\mathrm{C}$, et al. Senescence and death of primitive cells and myocytes lead to premature cardiac aging and heart failure. Circ Res 2003; 93: 604-613.

24. Maejima $Y$, Adachi S, Ito H, Hirao K, Isobe M. Induction of premature senescence in cardiomyocytes by doxorubicin as a novel mechanism of myocardial damage. Aging Cell 2008; 7: 125-136.

25. Leri A, Franco S, Zacheo A, Barlucchi L, Chimenti S, Limana $F$, et al. Ablation of telomerase and telomere loss leads to cardiac dilatation and heart failure associated with p53 upregulation. EMBO J 2003; 22: 131-139.

26. Estrada M, Espinosa A, Muller M, Jaimovich E. Testosterone stimulates intracellular calcium release and mitogen-activated protein kinases via a $\mathrm{G}$ protein-coupled receptor in skeletal muscle cells. Endocrinology 2003; 144: 3586-3597.

27. Nguyen TV, Yao M, Pike CJ. Androgens activate mitogenactivated protein kinase signaling: role in neuroprotection. $J$ Neurochem 2005; 94: 1639-1651.

28. Lu S, Tsai SY, Tsai MJ. Regulation of androgen-dependent prostatic cancer cell growth: androgen regulation of CDK2, CDK4, and CKI p16 genes. Cancer Res 1997; 57: 45114516.

29. Gregory CW, Johnson RT Jr, Presnell SC, Mohler JL, French FS. Androgen receptor regulation of $\mathrm{G} 1$ cyclin and cyclindependent kinase function in the CWR22 human prostate cancer xenograft. J Androl 2001; 22: 537-548.

30. Zhang X, Colombel M, Raffo A, Buttyan R. Enhanced expression of p53 mRNA and protein in the regressing rat ventral prostate gland. Biochem Biophys Res Commun 1994; 198: 1189-1194.

31. Liu PY, Death AK, Handelsman DJ. Androgens and cardiovascular disease. Endocr Rev 2003; 24: 313-340.

32. Handa RJ, Weiser MJ, Zuloaga DG. A role for the androgen metabolite, 5alpha-androstane-3beta,17beta-diol, in modulating oestrogen receptor beta-mediated regulation of hormonal stress reactivity. J Neuroendocrinol 2009; 21 : 351-358. 